\title{
Primary isolated bone marrow diffuse large B-cell lymphoma with the initial presentation as severe thrombocytopenia, successfully treated with chemotherapy: a case report and review of the literature
}

\author{
Hiroko Nishida ${ }^{1,2^{*}}$, Masao Hori ${ }^{3}$ and Katsuyuki Obara ${ }^{1}$ \\ Correspondence: hiroko@a2.keio.jp \\ 'Department of Internal of Medicine, Mito Red Cross Hospital, Ibaraki, Japan. \\ ${ }^{2}$ Department of Internal of Medicine, Keio University, School of Medicine, Tokyo, Japan. \\ ${ }^{3}$ Department of Pathology, Mito Red Cross Hospital, Ibaraki, Japan.
}

\begin{abstract}
Secondary bone marrow involvement of non-Hodgkin's lymphoma (NHL) is relatively common. However, primary isolated bone marrow involvement in NHL, successfully treated without any relapse, is quite rare, except in several leukemia/ lymphoma cases which are considered to primarily involve the bone marrow. We here report a case of primary bone marrow diffuse large B cell lymphoma (PBML/DLBCL), in which the patient presented a prolonged high-grade fever and systemic purpura due to severe thrombocytopenia, which was successfully treated with systemic chemotherapy and remains in complete remission (CR) at 2.5 years after the initial diagnosis. Review of 53 cases of PBML/DLBCL presented in the literature suggests that the prognosis for this eternity is unfavorable, but rituximab-based therapeutic strategies, including autologous stem cell transplantation are promising for improving their outcomes.
\end{abstract}

Keywords: bone marrow, PBML/DLBCL, thrombocytopenia, chemotherapy, complete remission

\section{Background}

Secondary bone marrow involvement of non-Hodgkin's lymphoma (NHL) is relatively common. However, primary isolated bone marrow involvement in $\mathrm{NHL}$, successfully treated without any relapse, is quite rare, except in several leukemia/lymphoma cases which are considered to primarily involve the bone marrow. We here report a case of primary bone marrow diffuse large $B$ cell lymphoma (PBML/DLBCL), with the initial presentation as severe thrombocytopenia, which was successfully treated with systemic chemotherapy and remains in complete remission (CR) at 2.5 years after the initial diagnosis. We also reviewed 53 cases of PBML/DLBCL. PBML is a very uncommon lymphoma with particular clinical features and heterogeneous histology and its outcome is unfavorable. Its recognition is essential for establishing accurate diagnosis and adequate therapeutic strategy.

\section{Case report}

A 66-year-old woman was admitted to our hospital, because of a prolonged fever of unknown origin with a 5 -week duration and because of general fatigue in March 2010. No antibiotics were effective. She had a previous history of breast carcinoma; stage I, treated by only mastectomy in 1988, without any adjunct chemotherapy or radiotherapy. On admission, her fever was $39^{\circ} \mathrm{C}$, pulse was $110 \mathrm{bpm}$ and regular, and blood pressure was 125/75 $\mathrm{mmHg}$. Physical examination revealed petechiae in the trunk and extremities, but both lymphadenopathy and splenomegaly were absent during the clinical course. Blood tests on admission showed the following: white blood cell (WBC) count 4,100/ $\mu$ l (Band+Seg 78.0\%, Mono 10.0\%, Lymph 12.0\%); hemoglobin ( $\mathrm{Hgb}) 11.0 \mathrm{~g} / \mathrm{dl}$; platelet count (PIt) $1.6 \times 10^{4} / \mu$; lactate dehydrogenase (LDH) 735 IU/l; AST $121 \mathrm{IU} / \mathrm{L} ;$ ALT $86 \mathrm{IU} / \mathrm{l}$; total bilirubin (T-Bil) 0.44 $\mathrm{mg} / \mathrm{dl}$; triglyceride (TG) $200 \mathrm{mg} / \mathrm{dl}$; C-reactive protein (CRP) $8.81 \mathrm{mg} / \mathrm{dl}$; ferritin 1,150 ng/ml; and soluble interleukin-2 receptor (sIL2-R) 13,100 U/ml (Table 1). Routine tests including blood coagulation profile, kidney functions, serum iron, vitamin B12, folic acid, and haptoglobin were normal. Tests for tuberculosis and viruses icncluding $\mathrm{HBV}, \mathrm{HCV}$, HIV, and CMV were negative. EBV-VCA IgG was $640 x$, EBV-VCA IgM was > 10x, and EBV-EBNA was 10x >, but the EBV DNA titer was within normal limits. Protein and immunoelectrophoresis, immunoglobulin, C3, C4 complement, anti-nuclear antibodies (ANA), rheumatoid factor (RF), and thyroid function were normal or negative. Repeated blood cultures were also normal. A cervical, chest, abdominal and pelvic computed tomography (CT) scan and Gallium scintigraphy demonstrated no 
Table 1. Laboratory findings at the initial presentation, after the first cycle of chemotherapy and 2.5 years after the initial diagnosis.

\begin{tabular}{|c|c|c|c|}
\hline \multicolumn{2}{|c|}{ At the initial presentation } & \multirow{2}{*}{$\begin{array}{c}\text { After the } 1^{\text {st }} \text { cycle of chemotherapy } \\
7,450 / \mu l\end{array}$} & \multirow{2}{*}{$\begin{array}{c}30 \text { months after the initial diagnosis } \\
7,020 / \mu \mathrm{l}\end{array}$} \\
\hline WBC & $4,100 / \mu \mathrm{l}$ & & \\
\hline Band Seg & $78 \%$ & $93.0 \%$ & $60.0 \%$ \\
\hline lymph & $12 \%$ & $6.5 \%$ & $31.5 \%$ \\
\hline mono & $10 \%$ & $0.5 \%$ & $6.5 \%$ \\
\hline Eosino & $0 \%$ & $0 \%$ & $0 \%$ \\
\hline Basi & $0 \%$ & $0 \%$ & $0 \%$ \\
\hline $\mathrm{RBC}$ & $352 \times 10^{4} / \mu l$ & $311 \times 10^{4} / \mu \mathrm{l}$ & $411 \times 10^{4} / \mu \mathrm{l}$ \\
\hline $\mathrm{Hgb}$ & $11.0 \mathrm{~g} / \mathrm{dl}$ & $9.5 \mathrm{~g} / \mathrm{d}$ & $13.0 \mathrm{~g} / \mathrm{dl}$ \\
\hline Hct & $33.0 \%$ & $28.8 \%$ & $39.9 \%$ \\
\hline PIt & $1.6 \times 10^{4} / \mu \mathrm{l}$ & $21.7 \times 10^{4} / \mu l$ & $17.4 \times 10^{4} / \mu \mathrm{l}$ \\
\hline Ret & $4.0 \%$ & $13.0 \%$ & $10.0 \%$ \\
\hline AST & $121 \mathrm{IU} / \mathrm{L}$ & $23 \mathrm{IU} / \mathrm{L}$ & $26 \mathrm{IU} / \mathrm{L}$ \\
\hline ALT & $86 \mathrm{IU} / \mathrm{L}$ & $47 \mathrm{IU} / \mathrm{L}$ & $16 \mathrm{IU} / \mathrm{L}$ \\
\hline LDH & $735 \mathrm{IU} / \mathrm{L}$ & $114 \mathrm{IU} / \mathrm{L}$ & $204 \mathrm{IU} / \mathrm{L}$ \\
\hline $\mathrm{TB}$ & $0.44 \mathrm{mg} / \mathrm{dl}$ & $0.88 \mathrm{mg} / \mathrm{dl}$ & $0.99 \mathrm{mg} / \mathrm{dl}$ \\
\hline BUN & $13.2 \mathrm{mg} / \mathrm{dl}$ & $22.9 \mathrm{mg} / \mathrm{dl}$ & $14.0 \mathrm{mg} / \mathrm{dl}$ \\
\hline $\mathrm{Cr}$ & $0.60 \mathrm{mg} / \mathrm{dl}$ & $0.42 \mathrm{mg} / \mathrm{dl}$ & $0.43 \mathrm{mg} / \mathrm{dl}$ \\
\hline TG & $200 \mathrm{mg} / \mathrm{dl}$ & $154 \mathrm{mg} / \mathrm{dl}$ & $163 \mathrm{mg} / \mathrm{dl}$ \\
\hline CRP & $8.81 \mathrm{mg} / \mathrm{dl}$ & $0.02 \mathrm{mg} / \mathrm{dl}$ & $0.09 \mathrm{mg} / \mathrm{dl}$ \\
\hline Feritin & $1,150 \mathrm{ng} / \mathrm{ml}$ & $150 \mathrm{ng} / \mathrm{ml}$ & $33.0 \mathrm{ng} / \mathrm{ml}$ \\
\hline sIL2-R & $13,100 \mathrm{U} / \mathrm{ml}$ & $1,470 \mathrm{U} / \mathrm{ml}$ & $492 \mathrm{U} / \mathrm{ml}$ \\
\hline \\
\hline \multicolumn{4}{|c|}{ CMV Antigenemia(-) } \\
\hline HIV & $(-)$ & & \\
\hline EBV -DNA & $<2 \times 10 / 10^{6}$ cell & & \\
\hline
\end{tabular}

lymphadenopathy, hepatosplenomegaly or other abnormal findings. Bone marrow aspiration revealed widespread infiltration of medium to large sized atypical lymphoma cells with distinct nucleoli, basophilic cytoplasm, and cytoplasmic vacuoles, whose immunophenotyping was CD5-/CD10-/ CD19+/CD20+/lg K+ (Figure 1a: May-Giemsa stain x1000, Figure 1b: Immunophenotyping panel). The number of megakaryocyte was decreased. Bone marrow biopsy in pathology review also demonstrated hypercellularity with widespread infiltration of large lymphoma cells positive for CD20 (L26), CD79a (mb-1), BCL6, BCL2, MUM1, but negative for CD3 (Figure 1, c: Hematoxylin and Eosin stain $\times 200, d$ : CD20 stain x200, e: CD79a stain x200, f: BCL6 stain x400, g: BCL2 stain x400, h: MUM1 stain x400, i: CD3 x200). In addition, pathologically, the proliferation of large lymphoma cells on the lumina of small vessels were not detected. EBV encoded small RNA (EBER) in situ hybridization was not also detected on bone marrow tissues. Immunohistochemical analysis showed that these cells were negative for MPO, glycophorin C, CD34, c-kit, and terminal deoxyribonucleotidyl transferase (TdT). Furthermore, cytogenetic analysis of the bone marrow cells demonstrated that 15 of the 20 cells analyzed showed complex chromosomal abnormalities; 47, XX, -1, add (3) (q11.2), add (4) (q31), t(6;14) (p21;q32), del (8) (q22q23), ?t(9;14) (p13;q32), add(12)(p11.2), der(12) $\operatorname{add}(12)(p 13) a d d(12)(q 22), \operatorname{der}(15) t(1 ; 15)$ (q11;p11.1)del(1) (q23q25), der (16)add(16)(p11.2)add(16)(q22), +18, add(20) (q11.2), +der(?)t(?;1)(?;p22) and 5 of the 20 cells showed
$46, X X$ (Figure 1j). Based on these results, the diagnosis of primary isolated bone marrow diffuse large B-cell lymphoma, non-germinal center B cell like (non-GCB type); stage IV (Age-adjusted International Prognostic Index: IPI score; high risk) was made. The patient was immediately treated with R-CHOP chemotherapy (rituximab; $375 \mathrm{mg} / \mathrm{m}^{2}$; day 1 , cyclophosphamide; $750 \mathrm{mg} / \mathrm{m}^{2}$; day 2, doxorubicin; $50 \mathrm{mg} /$ $\mathrm{m}^{2}$; day 2 , vincristine $1.4 \mathrm{mg} / \mathrm{m}^{2}$; day 2 , prednisolone; $100 \mathrm{mg} /$ body day 1 - day 5) and resulted in complete bone marrow response with no evidence of residual $B$ cell components of the bone marrow, assessed by immunohistochemistry on day 28 of the first cycle of the R-CHOP therapy (Table 1, Figure 2a: Hematoxylin and Eosin stain x200, b: CD20 stain x200 ). Chromosomal analysis also showed normal karyotype and CR was attained (Figure 2c). Her presenting symptoms, especially the fever gradually improved and she had a platelet level of $21.7 \times 10^{4} / \mu$ l. The level of $\mathrm{LDH}$ was decreased to $114 \mathrm{IU} / \mathrm{I}$, within normal limits $(<230 \mathrm{IU} / \mathrm{I})$ and sIL2-R have also decreased to $1,470 \mathrm{U} / \mathrm{ml}$. Baseline cerebrospinal fluid (CSF) examination was clear of atypical lymphoma cells, but prophylactic intrathecal methotrexate was given. She has been in $C R$ after receiving total 8 courses of R-CHOP chemotherapy, every 4 weeks. However, her low grade fever continued, so she continued to be treated with moderate doses of prednisolone. After 6 cycle of R-CHOP chemotherapy, prednisolone was discontinued, and she has remained free of fever. During the clinical course, she suffered from a varicella zoster virus (VZV) infection once, 


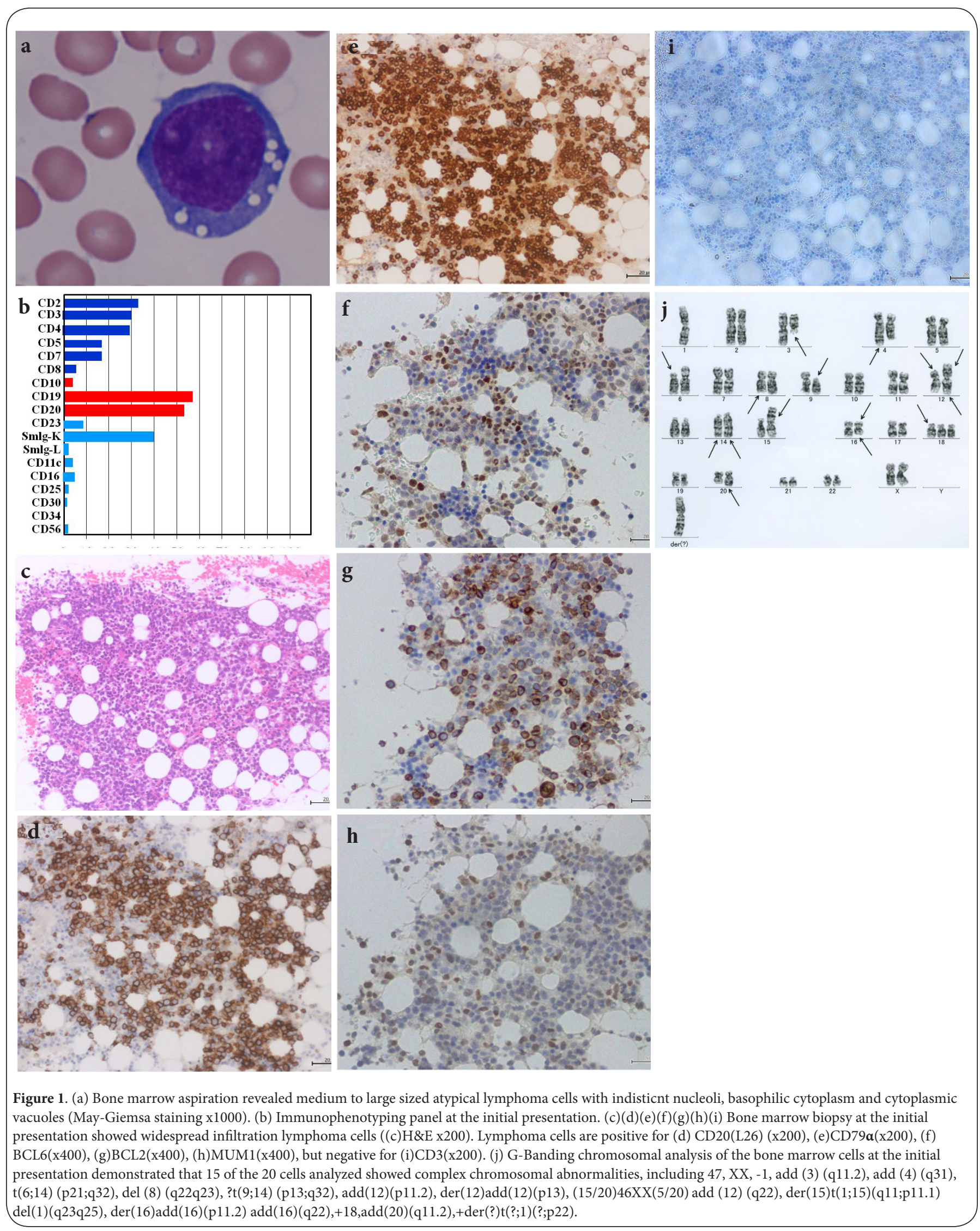



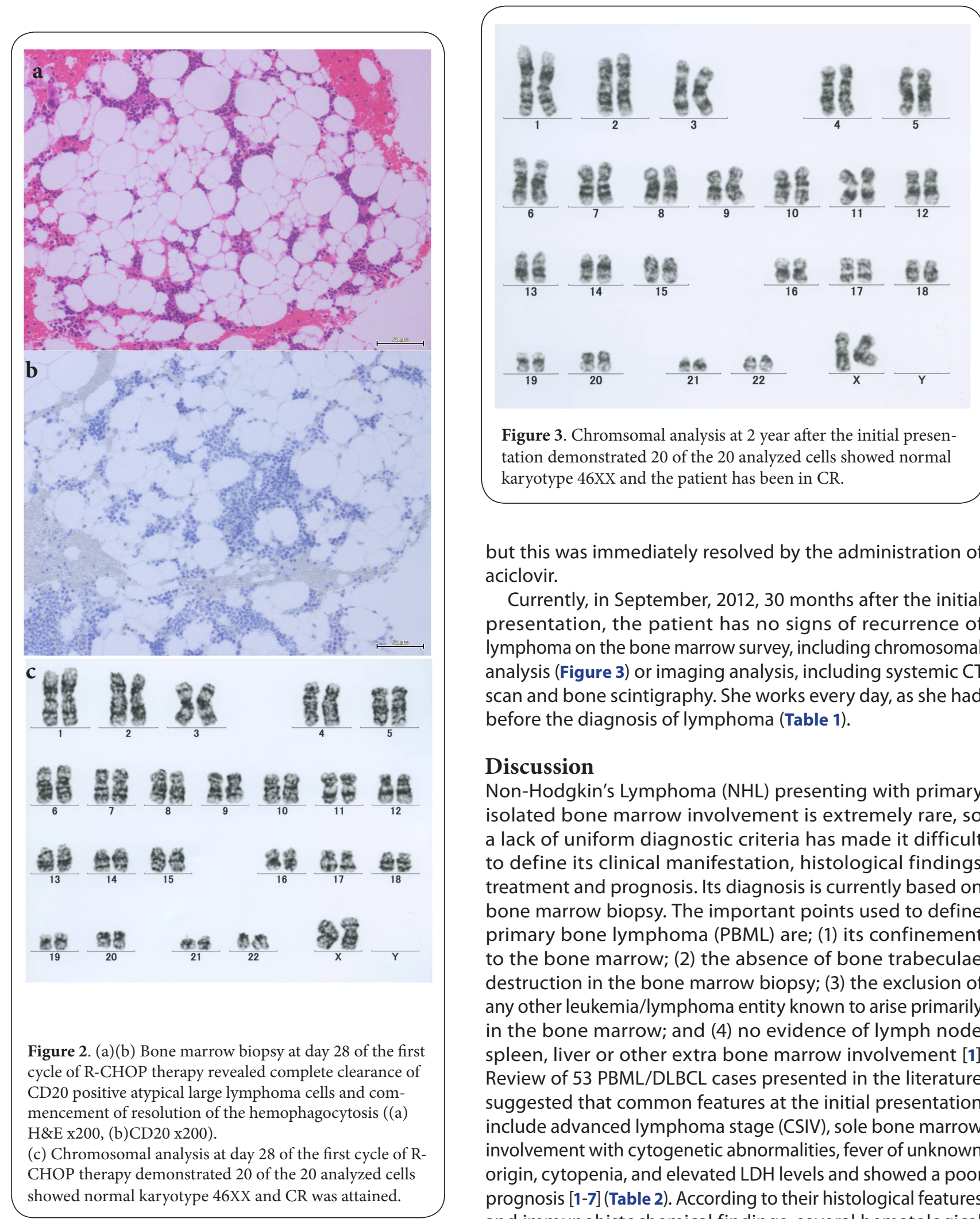

Figure 3. Chromsomal analysis at 2 year after the initial presentation demonstrated 20 of the 20 analyzed cells showed normal karyotype 46XX and the patient has been in CR.

but this was immediately resolved by the administration of aciclovir.

Currently, in September, 2012, 30 months after the initial presentation, the patient has no signs of recurrence of lymphoma on the bone marrow survey, including chromosomal analysis (Figure 3) or imaging analysis, including systemic CT scan and bone scintigraphy. She works every day, as she had before the diagnosis of lymphoma (Table 1).

\section{Discussion}

Non-Hodgkin's Lymphoma (NHL) presenting with primary isolated bone marrow involvement is extremely rare, so a lack of uniform diagnostic criteria has made it difficult to define its clinical manifestation, histological findings, treatment and prognosis. Its diagnosis is currently based on bone marrow biopsy. The important points used to define primary bone lymphoma (PBML) are; (1) its confinement to the bone marrow; (2) the absence of bone trabeculae destruction in the bone marrow biopsy; (3) the exclusion of any other leukemia/lymphoma entity known to arise primarily in the bone marrow; and (4) no evidence of lymph node, spleen, liver or other extra bone marrow involvement [1]. Review of 53 PBML/DLBCL cases presented in the literature suggested that common features at the initial presentation include advanced lymphoma stage (CSIV), sole bone marrow involvement with cytogenetic abnormalities, fever of unknown origin, cytopenia, and elevated LDH levels and showed a poor prognosis [1-7] (Table 2). According to their histological features and immunohistochemical findings, several hematological malignancies arose primarily in the bone marrow. Kajiura et al., compared the asian variant of intravascular large B-cell 
Nishida et al. Journal of Cancer Therapeutics \& Research 2012,

http://www.hoajonline.com/journals/pdf/2049-7962-1-28.pdf

doi: $10.7243 / 2049-7962-1-28$

Table 2. Summary of studies describing PBML/DLBCL with thrombocytopenia at the initial presentation.

\begin{tabular}{|c|c|c|c|c|c|}
\hline Author & & $\begin{array}{l}\text { Thro } \\
\text { at th }\end{array}$ & $\begin{array}{l}\text { ocytopenia } \\
\text { itial diagnosis }\end{array}$ & Outocome & Survival \\
\hline Martinez A, et al. & 15 & $7 / 15$ & $\begin{array}{l}\text { CHOP(3)R-CHOP(7)COP(1)HD-CHOP(1) } \\
\text { CHOEP(1)VACOPB(1) } \\
\text { Supportive care(1) }\end{array}$ & Dead(10)Alive(5) & $\begin{array}{l}<7 \text { days(Alive)-2.4years(Dead) } \\
<7 \text { days(Alive)-2.4years(Dead) }\end{array}$ \\
\hline Chang $\mathrm{H}$, et al. & 12 & $7 / 12$ & $\begin{array}{l}\text { CHOP(3)R-CHOP(3)COP(1)R-COP(1) } \\
\text { Auto-PBSCT(1)Supprotive care(1) }\end{array}$ & Dead(8)Alive(4) & $\begin{array}{l}<1 \text { month(Dead)-56months(Alive) } \\
<1 \text { month(Dead)-56months(Alive) }\end{array}$ \\
\hline Alvares CL, et al. & 3 & $2 / 3$ & $\begin{array}{l}\text { R-CHOP(1)CHOP(1) } \\
\text { CHOP/COP+MIT+MTX }(1)\end{array}$ & Dead(2)Alive(1) & $<1$ month(dead)-9months(Dead) \\
\hline Hishizawa M, et al. & 1 & ND & R-CHOP+Auto-PBSCT & Alive & 12 month(Alive) \\
\hline Barton JC, et al. & 7 & $0 / 7$ & $\begin{array}{l}\text { VP/COP+Pro/ADR+Bleo+DTIC/ } \\
\text { COP+BCNU/L-asp(1) } \\
\text { CBL-PSL(1)ADR+Bleo+DTIC/Bleo+ } \\
\text { DTIC(1), CBL+PSL/PSL(1), } \\
\text { CBL+PSL/PSL/COP+Ara-C(1),PSL(2) }\end{array}$ & Dead(4)Alive(3) & 2-54months(Alive) \\
\hline
\end{tabular}

Kajiura D, et al. $\quad 9$ ND

Dead(8)Alive(1) 1.5weeks(Dead)-37month(Dead)

MIT:mitoxantrone, MTX:methotrexate, Pro:procarbazine, ADR:adriamycin, Bleo:bleomycin, DTIC:dimethyl triazeno imidazole carboxamide, CBL:chrlorambucil, PSL;prednisolone, Ara-C:cytosine arabinoside.

lymphoma (AIVL) with PBML, however our case revealed no lymphoma cell infiltrations in the sinusoids of the bone marrow, so the diagnosis of AIVL was excluded [8]. Another diagnosic possibilities, including acute lymphoblastic leukemia (ALL), lymphoblastic lymphoma (LBL), chronic lymphocytic leukemia (CLL), small lymphocytic lymphoma (SLL), mantle cell lymphoma (MCL), Burkitt's lymphoma $(B L)$, follicular lymphoma (FCL), splenic marginal zone lymphoma (SMZL), and hairly cell leukemia $(\mathrm{HCL})$ were also excluded. Furthermore, in order to avoid the overlap between primary bone lymphoma and PBML, a systemic CT scan showed normal findings. The mandatory absence of any localized bone tumor and the absence of evidence of trabeculae destruction in the bone marrow biopsy were also confirmed.

In our case, at the initial presentation, viral infections, such as EBV, CMV, HIV were considered to be some of the differential diagnosis or complications, as the cause of unknown fever, associated with thrombocytopenia. Especially, the diagnosis of EBV associated hemophagocytic syndrome or EBV positive diffuse large B-cell lymphoma of the elderly was highly suspected, however EBV DNA load in the peripheral blood was within normal limits and EBER in situ hybridization in the bone marrow tissue was negative (data now shown), so finally diagnosis, related to EBV infection was ruled out.

Recently, there have been significant advances in cancer imaging techniques. PET/CT becomes popular in the evaluation of patients with malignant lymphoma and has been shown to be more sensitive and specific than contrast-enhanced CT scan for the evaluation of nodal and extranodal involvements of lymphoma. Bone marrow involvement is one of the most important prognostic factors in patients with lymphoma, thus in patients with high grade lymphoma or intermediate grade lymphoma, like our case is associated with significantly shorter survival. Therefore, bone marrow biopsy is now included as a part of the essential evaluation for the initial staging in patients with malignant lymphoma. However, bone marrow biopsy is an invasive procedure with a restrictive reliability, as only a limited area of the bone marrow is investigated, shown as a false negativity in up to $80 \%$ in a unilateral iliac crest biopsy, compared to bilateral iliac biopsies. Some of discordant rate was reported between bone marrow biopsy and FDG-PET/ CT in detecting bone marrow involvement of DLBCL and although, there are no established guidelines to interpret bone marrow involvement by FDG-PET/CT in patients with newly diagnosed malignant lymphoma. However, patients with concordant bone marrow involvement had inferior survival compared to those with discordant marrow involvement, so additional results on the role of FDG-PET/CT in detecting bone marrow involvement may available and FDG-PET/CT may be used as a complementary rather than an alternative tool in detecting bone marrow involvement in patients with newly diagnosed DLBCL [9-11].

Review of 53 PBML/DLBCL cases presented in the literature suggests that most reported PBML cases have been diffuse large $B$ cell lymphoma (DLBCL)(Table 1)[1-7]. 
Martinez et al., analyzed 21 PBML cases and found that 19 cases were $B$-cell lymphomas ( 4 cases; FCL, 15cases; $\mathrm{DLBCL}$ ) and 2 cases were peripheral T cell lymphoma (PTCL) [8]. Furthermore, PBML/DLBCL cases that initially presented with severe thrombocytopenia, successfully treated without any relapse were extremely rare and had showed especially unfavorable outcomes, with a median overall survival (OS) of from 1 month to 2.4 years [1]. Changs et al., also reported these 12 cases and one of these cases reveals OS of 56months with CHOP therapy, however this case relapsed ${ }^{2}$. In previous reports, in most cases, the first therapeutic option is R-CHOP therapy, however considering their unfavorable prognosis, intensive chemotherapy, including dose-modified R-ESHAP (rituximab, etoposide, cisplatin, cytarabine, prednisolone) or dose-modified R-hyper-CVAD (rituximab, cyclophosphamide, vincristine, doxorubicin, dexamethasone) may be one of the therapeutic options even in the elderly patients without any organ dysfunctions or complications. Also, especially in younger patients without any organ dysfunctions or complications, up-front autologous stem cell transplantation may be one of the therapeutic options. However in our case, chiefly due to bone marrow suppression after R-CHOP chemotherapy, it is impossible to repeat chemotherapy every 3 weeks. So, after confirming the recovery of neutrophil count in the peripheral blood, the next course of R-CHOP therapy was initiated, every 4 weeks. Our case also belong to high risk group, according to IPI score and the presence of chromosomal abnormalities. Despite these backgrounds, our case has been in CR until now without any relapse signs, 2.5 years after the initial presentation. Several previous cases eventually developed extranodal relapse, such as central nervous system (CNS) relapse, so we also continue to take care of CNS involvement with the administration of prophylactic intrathecal methotrexate [1-3].

In conclusion, we reported unique case of PBML/DLBCL initially presenting with severe thrombocytopenia was successfully treated with systemic chemotherapy and has remained in CR for 2.5 years in September 2012. In cases with unknown fever and thrombocytopenia, PBML/DLBCL may be included in the differential diagnosis, as well as viral infections, and it is important to establish the exact diagnosis as quickly as possible and immediately initiate adequate therapies.

\section{Competing interests}

The authors declare that have no competing interests.

\section{Authors' contributions}

H.N. performed the described studies, analyzed and interpreted data, and prepared the mauscript. M.H. analyzed and interpreted data of pathology section. K.O. analyzed and interpreted data, and prepare the manuscript.

\section{Acknowledgements}

The authors would like to thank the doctors and nurses of the internal medicine in-patient and out-patient ward of Mito Red Cross Hospital for providing excellent patient care, and Hiroshi
Suzuki, at Keio University Hospital, for his technical assistance. Publication history

Received: 29-Aug-2012 Revised: 24-Sep-2012

Accepted: 09-Oct-2012 Published: 15-Oct-2012

\section{References}

1. Martinez A, Ponzoni M, Agostinelli C, Hebeda KM, Matutes E, Peccatori J, Campidelli C, Espinet B, Perea G, Acevedo A, Mehrjardi AZ, Martinez-Bernal M, Gelemur M, Zucca E, Pileri S, Campo E, LopezGuillermo A, Rozman M: Primary bone marrow lymphoma: an uncommon extranodal presentation of aggressive non-hodgkin Iymphomas. Am J Surg Pathol 2012, 36:296-304. I Article I PubMed

2. Chang H, Hung YS, Lin TL, Wang PN, Kuo MC, Tang TC, Wu JH, Dunn $P$, Shih LY: Primary bone marrow diffuse large B cell lymphoma: a case series and review. Ann Hematol 2011, 90:791-796. | Article | PubMed

3. Alvares CL, Matutes E, Scully MA, Swansbury J, Min T, GruszkaWestwood AM, Atkinson S, Hilditch B, Morilla R, Wotherspoon AC, Catovsky D: Isolated bone marrow involvement in diffuse large $B$ cell lymphoma: a report of three cases with review of morphological, immunophenotypic and cytogenetic findings. Leuk Lymphoma 2004, 45:769-775. | Article | PubMed

4. Hishizawa M, Okamoto K, Chonabayashi K, Kaneko H, Watanabe M, Tsudo M: Primary large B-cell lymphoma of the bone marrow. Br J Haematol 2007, 136:351. I Article I PubMed

5. Barton JC, Conrad ME, Vogler LB, Parmley RT: Isolated marrow Iymphoma: an entity of possible T-cell derivation. Cancer 1980, 46:1767-1774. I Article I PubMed

6. Kajiura D, Yamashita Y, Mori N: Diffuse large B-cell lymphoma initially manifesting in the bone marrow. Am J Clin Pathol 2007, 127:762769. | Article | PubMed

7. Niainle F, Hamnvik OP, Gulmann C, Bermingham C, Kelly J, Mc Evoy P, Murphy P: Diffuse large B-cell lymphoma with isolated bone marrow involvement presenting with secondary cold agglutinin disease. Int J Lab Hematol 2008, 30:444-445. I Article I PubMed

8. Takahashi T, Tsukuda H, Itoh H, Kimura H, Yoshimoto M, Tsujisaki M: Primary and isolated adult T-cell leukemia/lymphoma of the bone marrow. Intern Med 2011, 50:2393-2396. I Article I PubMed

9. Hong J, Lee Y, Park Y, Kim SG, Hwang KH, Park SH, Jeong J, Kim KH, Ahn JY, Park S, Park J, Lee JH: Role of FDG-PET/CT in detecting lymphomatous bone marrow involvement in patients with newly diagnosed diffuse large B-cell lymphoma. Ann Hematol 2012, 91:687-695. I Article I PubMed

10. Muzahir S, Mian M, Munir I, Nawaz MK, Faruqui ZS, Mufti KA, Bashir $H$, Uddin N, Siddiqui N, Maaz AU, Mahmood MT: Clinical utility of (1) (8)F FDG-PET/CT in the detection of bone marrow disease in Hodgkin's lymphoma. Br J Radiol 2012, 85:e490-496. I Article I PubMed

11. Ngeow JY, Quek RH, Ng DC, Hee SW, Tao M, Lim LC, Tan YH, Lim ST: High SUV uptake on FDG-PET/CT predicts for an aggressive B-cell lymphoma in a prospective study of primary FDG-PET/CT staging in lymphoma. Ann Oncol 2009, 20:1543-1547. I Article I PubMed

\section{Citation:}

Nishida H, Hori $\mathrm{M}$ and Obara K: Primary isolated bone marrow diffuse large $B$-cell lymphoma with the initial presentation as severe thrombocytopenia, successfully treated with chemotherapy: a case report and review of the literature. journal of Cancer Therapeutics and Research 2012, 1:28.

http://dx.doi.org/10.7243/2049-7962-1-28 